\title{
BIRDWATCHING AS A NEW RESOURCE FOR SERBIAN ECO-TOURISM DEVELOPMENT
}

\author{
Mario Lukinović ${ }^{1}$ \\ Larisa Jovanović ${ }^{2}$
}

DOI: https://doi.org/10.31410/tmt.2020.271

\begin{abstract}
The topic of this paper is the branding of the tourist offer of birdwatching in Belgrade. Although it brings significant income to the world, birdwatching in Serbia is still not adequately recognized and there is no developed offer of programs for bird watchers. Serbia has no access to the sea and must rely on eco-tourism, primarily spa and rural tourism. Unlike other types of tourism, birdwatching does not require significant investments in infrastructure. It is practiced by nature lovers of all ages and develops in all areas where birds can be observed, from backyards, parks to hard-to-reach and untouched parts of nature. Promoting this type of hobby can have a significant impact on spending more time in nature, as well as raising awareness of the need to preserve nature. The uniqueness of the birdwatching offer on the territory of the city of Belgrade is reflected in the presence of a large number of different habitats in a relatively small area, so it is possible to see almost in one focus and the Whitetailed eagle and the wetland bird.
\end{abstract}

Keywords: Birdwatching, Birds, Branding, Tourism, Belgrade, Serbia.

\section{INTRODUCTION}

$\mathrm{T}$ he process of globalization has reduced the distance between tourist destinations and at the same time increased their competitiveness. In order to attract visitors, places compete in building reputation, image, identity and brand. Given that many authors dispute the possibility of building a place brand, we will clarify this term and the procedure for branding locations. A brand is much more than its symbols and the characteristics that distinguish it, it represents the relationship between the customer and the brand (Schultz, Barnes, 1999). The emotions it evokes in the consumer determine its value. Building a distinctive brand identity is the most effective and fastest form of market communication (Ilić et al., 2017). When attracting tourists, destinations, by pointing out their qualities, try to evoke positive associations with consumers (Morgan et al., 2015). The competitiveness of a certain tourist locality is reflected in its potential to attract visitors (Mladenović, Bojičić, 2020). The branding process is based on arousing emotions in consumers. Tens of thousands of tourist locations compete in attracting tourists, so it is necessary to send customers a strong message about their products (Gobe, 2001; Milićević et al., 2019).

Serbia has considerable, diverse resources (Marković et al., 2018), and favorable conditions for the development of eco-tourism (Dašić, Anufriev, 2018). By analyzing the natural resources and eco-potentials of Serbian tourist destinations it is concluded that their attractiveness ensures the possibility for diverse development of eco-tourism (Živković, 2018).

Faculty of Law, Union University, Belgrade, Serbia

Alfa BK University, 3 Palmira Toljatija, 11070 Belgrade, Serbia 


\section{RESEARCH METHODOLOGY}

The aim of the paper was devoted to the implementation of the research process in the area of birdwatching by the application of the following methods:

- Basic methods: analysis and synthesis, induction and deduction.

- General scientific methods: descriptive and comparative analysis.

The objectives were focused on diversification of tourist portfolio in Belgrade and other tourist destinations with the purpose of Serbian eco-tourism development.

Starting from the conceptual definition of branding and determination of birdwatching, in order to reach a descriptive level of scientific knowledge, examples of good practice in the world were considered, in order to reach a scientifically acceptable explanation. As, unlike the natural sciences, the social sciences cannot investigate phenomena in experimental conditions, the paper analyses the current situation as well as the possibilities for improvement. Through basic data sources, such as relevant bibliographic units (books, textbooks, magazines, etc.), and modern electronic data sources, analyzes were made that aimed to shed light on a topic that was only partially covered in scientific and professional circles in the Republic of Serbia.

The scientific goal is expressed in the contribution of theoretical knowledge about birdwatching in the area of Belgrade and its surroundings, with special reference to the potential that this insufficiently exploited type of tourism has in our country and the possibilities for its improvement through the destination branding process.

The social goal is to determine the elements of the comparative advantage that Belgrade has concerning other tourist destinations, especially in the segment of birdwatching tourism and ecotourism in order to target improve the tourist presentation of Belgrade.

\section{BRANDING TOURISM DESTINATIONS}

For most, branding seems simple and comes down to persistently repeating certain, often exaggerated claims about a particular product or service. However, branding is not so simple (Olins, 2003). It sublimates a multitude of different activities that can help achieve the ultimate goal, and that is the desired perception of a particular brand (Okanović et al., 2020). These activities usually include advertising, PR activities, trademark, design, geographical indication of origin, eco-labels, etc. (Štetić, Trišić, 2020).

The Internet has offered types of direct and indirect communication on which an increasing number of consumers rely. When choosing the tourist potential, natural resources of destination users increasingly first check the appearance and prices of accommodation facilities, experiences and evaluations of other users via the Internet (Virijević Jovanović et al., 2020).

Smaller social communities, especially those to which passionate members of certain social segments belong, are particularly coherent. Numerous specialized portals of nature lovers offer a lot of information about tourist sites around the world. The community of ornithologists stands out among them. Thanks to several bird lovers from Serbia, it is possible to permanently monitor the appearance of certain species in localities throughout Serbia, which is the primary motive for birdwatchers. In order to further promote birdwatching, they need to be given more 
significant support and not allow this great tourist potential to depend on their enthusiasm. The promotion of this type of tourism does not require large investments in marketing but requires permanent care for all segments that are important for its popularization. The possibility for tourists to see the medieval fortress Kalemegdan or the Millennium Tower Gardoš and more than 200 different species of birds in one view, actually located in the strict city center, is undoubtedly a great tourist potential that must be wisely and carefully branded.

\section{BELGRADE AS A TOURIST DESTINATION}

Belgrade is located at the crossroads of Eastern and Western Europe leading to the shores of the Aegean Sea, Asia Minor and the Middle East. The city lies on a waterway that connects Western European and Central European countries with the countries of Southeast and Eastern Europe. Ships come to its port from both sides of the waterway: North Sea - Atlantic - Black Sea. Visiting cities is the most dynamic form of travel after cruising, which in the last five years has recorded a spectacular growth of almost 60\% (Tourism Development Strategy of the City of Belgrade 2020-2025). Apart from the larger number of tourists that are generated through cruise visits, nautical tourism has great potential for the arrival of tourists. It is estimated that there are over 15 million vessels in Europe, and several million more are produced in the world every year. This is great potential not only for coastal states but also for continental states whose rivers, canals and lakes make an interesting waterway for nautical tourists (Štetić et al., 2014).

Due to its geographical position and connection with the whole of Europe and the Middle East, Belgrade is an excellent city break destination. This type of tourism is one of the most popular types of tourism in the world with almost $50 \%$ of tourist trips. In order for a city to be assessed as a good city break destination, it needs to meet several parameters. Easy and affordable accessibility is one of the key factors, the specificity of the location, gastronomic offer, the price of non-board services, security, accommodation prices, cultural and historical heritage, events (festivals, concerts, sports events, etc.), information systems, kindness hosts, attractions, etc. Belgrade meets the vast majority of these parameters at the highest level, especially because city break tourists spend most weekends or extended weekends in their destinations and want to see as much as possible. Some authors distinguish two basic groups of cities break tourists, those for whom the cultural activities of the city are the main motive for visiting a tourist destination and those who want to get to know the atmosphere of the city through local gastronomy, entertainment, nightlife and the like (Štetić et al., 2014). Promoting birdwatching as a specific local tourist offer of Belgrade, not only would complete its rich tourist offer but would also significantly contribute to the promotion of Belgrade as a tourist destination that is attractive to nature lovers. Also, one-sided tourism no longer meets the needs of modern tourists looking for heterogeneity of offers. This is especially true for tourists in urban areas who base their visit not only on vacation but on the entire offer. Diversity of supply generates new jobs, economic progress, regenerates urban pockets, etc.

Belgrade's position on one of the most important rivers in Europe has been an underutilized potential in the past. The reconstruction of fortresses on the banks of the Danube in Serbia certainly strengthens the tourist potential of Serbia and Belgrade, especially bearing in mind that nautical tourism records the highest growth rates of all branches of tourism (Štetić et al., 2014).

As a rare city of two million inhabitants, Belgrade has a wide offer, in addition to monuments, museums and galleries, theaters, congresses and education, restaurants and bars, shopping, sports 
and cultural events, music concerts, fairs, unforgettable gastronomic offer and nightlife. make it unique. In a period of just ten years 2009-2019. the number of tourists in Belgrade has doubled. Most tourists come from China, Germany, Turkey, Poland and Croatia, Slovenia and Romania. The largest growth in tourist traffic was achieved by tourists from China, Israel and the USA.

In recent years, Belgrade has become connected with many cities and low-cost airlines, which, along with favorable accommodation prices and non-board services, has further influenced the increase in the number of tourists.

Table 1. Trends in the number of tourists in the city Belgrade for the period 2009-2019. years

\begin{tabular}{|c|c|c|c|c|c|c|c|c|c|c|}
\hline 2009. & 2010. & 2011. & 2012. & 2013. & 2014. & 2015. & 2016. & 2017. & 2018 & 2019. \\
\hline 602.034 & 618.454 & 619.124 & 660.674 & 718.943 & 753.742 & 807.607 & 913.150 & 1.035 .205 & 1.160 .582 & 1.258 .348 \\
\hline
\end{tabular}

Source: The Statistical Office of the Republic of Serbia

\section{NATURAL ASSETS OF BELGRADE}

The role and importance of ecotourism is growing. Eco-tourists, more often than other tourists, express their commitment to the preservation of natural values through the transmission of impressions about the destination they visited (Vujović et al., 2012). They more often record and share records from their travels, publish impressions in their blogs, have public appearances, etc. There are many definitions of eco-tourism, according to Todorović and Štetić (2009), eco-tourism is ,a form of tourism where ecologically conscious individuals and groups participate, who try to reduce the effects of mass tourism by acting on the environment."

Although many equate ecotourism with isolated, distant destinations, ecotourism includes parks, green areas, cultural heritage and heritage, and as such can be applied in urban areas (Malinić, 2016), and especially to protected natural assets in cities. Belgrade is located on the border between the Pannonian Plain and the Balkan Peninsula with a mild continental climate that creates geographical conditions for vegetation consisting of a mosaic of grass formations in the north, forest vegetation in the south, oak forests in the west, hydrogenic and chernozem soils in a zone from the Sava and the Danube River towards the south (Durdić et al., 2011).

As birdwatching tourism is a subcategory of nature-based tourism, a significant proportion of tourists engaged in birdwatching are also interested in nature tours. Belgrade can offer a wide and diverse network of protected preserved natural areas on its territory. In the area of Belgrade, protected natural assets are: Landscape of Exceptional Features Avala, Landscape of Exceptional Features Kosmaj, Natural property The Great War Island, Strict nature reserve Forest of Silver linden, Strict nature reserve Forest of Pedunculate oak and Hornbeam near Hajduk fountain, Natural monument „Bajford's forest”, Natural monument Bojćinska forest, Natural monument Miljakovačka forest, Natural monument ,Jevremovac' Botanical Garden, Topčiderski park, Natural monument Akademski park, Natural monument Pionirski park, Natural monument Vine in Zemun, Natural monument Cypress on Dedinje, Natural monument Hrast on Cvetni trg, Natural monument Three Pedunculate oaks Bare, Natural monument Tisa in Požeška street, Natural monument Tisa in Botićeva, Natural monument Cedar tree, Natural monument Trees in Zemun park, Natural monument ,Mašin majdan' Senonian shelf, Sea Neogene shelf - Kalemegdan, Natural monument Obrenovački zabran, Natural monument Platan near Miloš konak, Natural monument Platan in Vračar, Natural monument Ginkgo tree, Light profile Chapel in Batajnica, Miocene shelf - Tašmajdan, Nature monument „Zvezdarska šuma”, Nature monument „Kesten na Dorćolu”, 
Nature monument „Lalino drvo”, Nature monument „Lipovička šuma - Dugi rt”, Nature monument Two Yew trees of Cathedral Church, Nature monument Two Himalayan pine trees, Nature monument A group of pedunculate oak trees near Jozić hut, Natural monument of groups of trees on Andrićev trg and Kalemegdan and a protected mushroom habitat on Ada Ciganlija.

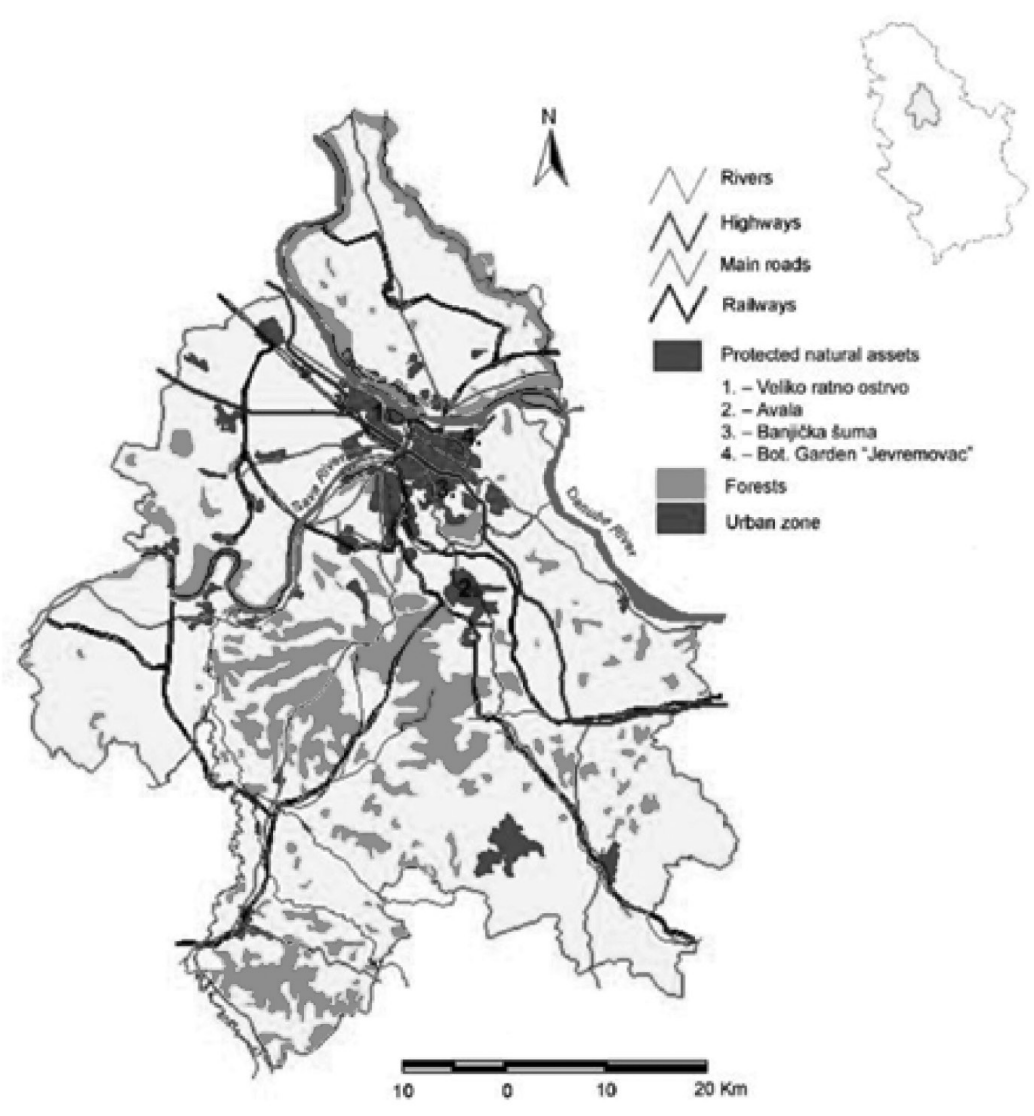

Figure 1. Selected protected natural assets in Belgrade area

Source: Durdić et al., 2011

Avala is a mountain located 16.5 kilometers from the center of Belgrade. Although it is a low mountain, it is characterized by a great diversity of flora and fauna (594 plant species have been found so far, which can be systematically classified into two classes, 86 families and 317 genera). In addition to roe deer, rabbit, badger, squirrel, gray down, marten beetle, marten squirrel, partridge, pigeon, quail, forest snipe, fox, common buzzard, harrier, hawk, barn owl, coward, pupa, roe deer, rabbit, pheasant, field partridges, wild boars can also be encountered. Of the 67 bird species seen on Avala, 21 are regular (avalinfo.com). The landscape of the exceptional features of Kosmaj is also rich in flora and fauna. Almost 600 plant species, about a hundred species of birds, 300 edible, medicinal and poisonous fungi, 50 mammals and a large number of insects have been registered on this mountain. Rich forests cover an area of 670 ha, mostly deciduous (oak, Turkey oak, beech and hornbeam) and coniferous trees (pine, fir, spruce and cedar). Veliko Ratno ostrvo includes two river islands (Veliko and Malo ratno ostrvo) which form a unique geological formation on an area of about 211 ha. This protected natural asset is located in the very center of Belgrade, almost at the confluence of the Sava and the Danube. Topčider park is the fifth most visited tourist destination in Belgrade. It spreads over an area of about 13 hectares, it used to be a residential park, and today it attracts mostly domestic visitors (Lakićević, Srđević, 2011). Topčider Park is adorned with a large number of plants (78 species) which is a consequence of the connection with the forest Košutnjak, of which it is an integral part (Stavretović et al., 2011). The Nature 
Monument Zvezdarska Šuma represents an important part of the city's ecosystem and one of the favorite picnic spots of its citizens. So far, 136 plant species have been recorded in its area, of which rare, relict, endemic and endangered tree species stand out (white ash, white poplar, royal jelly, cherry, birch, embroidery, elm, bear hazel and walnut. This green surface is a typical urban biotope where 48 species of birds of different protection status can be found (zelenilo.rs).

\section{BIRDWATCHING}

Birdwatching is a sustainable source of long-term and reliable financing (Kerlinger, 1992), which can significantly contribute to sustainable nature management (hunting and fishing), preservation of local customs and culture. Birdwatching involves observing different species of birds in their natural habitat, either with the naked eye or with the help of optical aids and photographic equipment. Although greater interest in wild birds was expressed around 1880 in Great Britain, and later in the Scandinavian countries, the Netherlands, Germany, Switzerland and others. until the beginning of the 20th century, this scientific and sports activity did not exist. Interest in birds was predominantly associated with hunting (Rajević et al., 2016).

Birdwatching is the fastest growing outdoor activity in America, bringing together about $20 \%$ of U.S. citizens. Among wildlife lovers in the United States, birds attract as much as $72 \%$ of this group of tourists. According to the latest available National Report (National Survey of Fishing, Hunting, and Wildlife-Associated), 45.1 million Americans engage in birdwatching, spending an average of 96 days a year observing birds, of which 16 days were away from home (National Survey of Fishing Hunting, and Wildlife-Associated, 2016). In Great Britain, as much as 500 million euros are spent annually on this activity, which surpassed fishing as a hobby, which has been number one for decades. The UK is the second-largest market for birdwatching tourism in the world, with around six million people regularly engaged in bird watching, it is also the seat of the largest organization for the protection of birds in Europe (Royal Society for the Protection of Birds) with more than a million members (White, 2019). In proportion to the population, the largest association of birdwatchers is in the Netherlands. Tourists who observe birds do so throughout the year and are directed mainly towards facilities of smaller accommodation capacity and authentic gastronomic offer.

Interest in bird biodiversity is wide (Kolstoe, Cameron, 2017), there are several different groups among bird observers, depending on the nature of their observation. Twitchers have a focus on observing as many birds as possible and are equipped with their equipment (telescopes, binoculars, etc.). They are willing to cover great distances to see rare species that they can put on their lists. Casual twitchers represent almost a third of this type of tourists, they are not strictly dedicated to birdwatching, but the primary goal of their trip is interest in nature and activities in nature. Birdwatching enthusiasts make up the largest segment of bird watchers and although they are also interested in other activities (especially cultural) they are the biggest consumers among this group of tourists. They respond very favorably to all marketing offers on the market, especially those that include activities related to local cultural heritage (Birdwatching tourism from Europe, 2017).

Urban bird watching also has its admirers, they are not attracted by hours of waiting in nature to see rare birds, but they tend to observe birds as urban guerrillas, where they climb walls, run railways and streets carrying bird watching equipment that is smaller and more modest. (Hinchliffe, 2010).

Belgrade provides opportunities for active observation of all these groups. 


\section{BIRDWATCHING IN SERBIA}

Birds are the most diverse class of terrestrial vertebrates with between 10 and 11 thousand species known so far (Stanković, 2021). So far, 352 bird species have been recorded in the Republic of Serbia (Šćiban et al., 2015), of which 333 species can be seen regularly. Five species that are among the endangered species: Ferruginous Duck (Aythya nyroca), Imperial Eagle (Aquila heliaca), Lesser Kestrel (Falco naumanni), Great Bustard (Otis tarda) and Corncrake (Crex crex). They cause special attention among the birds in the sky of Serbia: Pygmy Cormorant (Microcarbo pygmeus), Black Stork (Ciconia nigra), Glossy Ibis (Plegadis falcinellus), Spoonbill (Plateinae), Griffon Vulture (Gyps fulvus), Saker Falcon (Falco cherrug), Common Crane (Grus grus) and Collared Flycatcher (Ficedula albicollis).

The most attractive locations for birdwatching in Serbia are Ludaš Lake, Gornje Podunavlje, Slano Kopovo, Great Bustard Pastures, Rusanda Lake, Carska Bara, Kikinda, Tamiš River floodplain, Fruška Gora, Zasavica, Deliblato Sands, Djerdap Gorge, Ovčar-Kablar Gorge, Uvac Gorge, Mountain Maljen, Fantast Castle, Bečej Fishponds, Gruža Lake (Birdwatch Serbia).

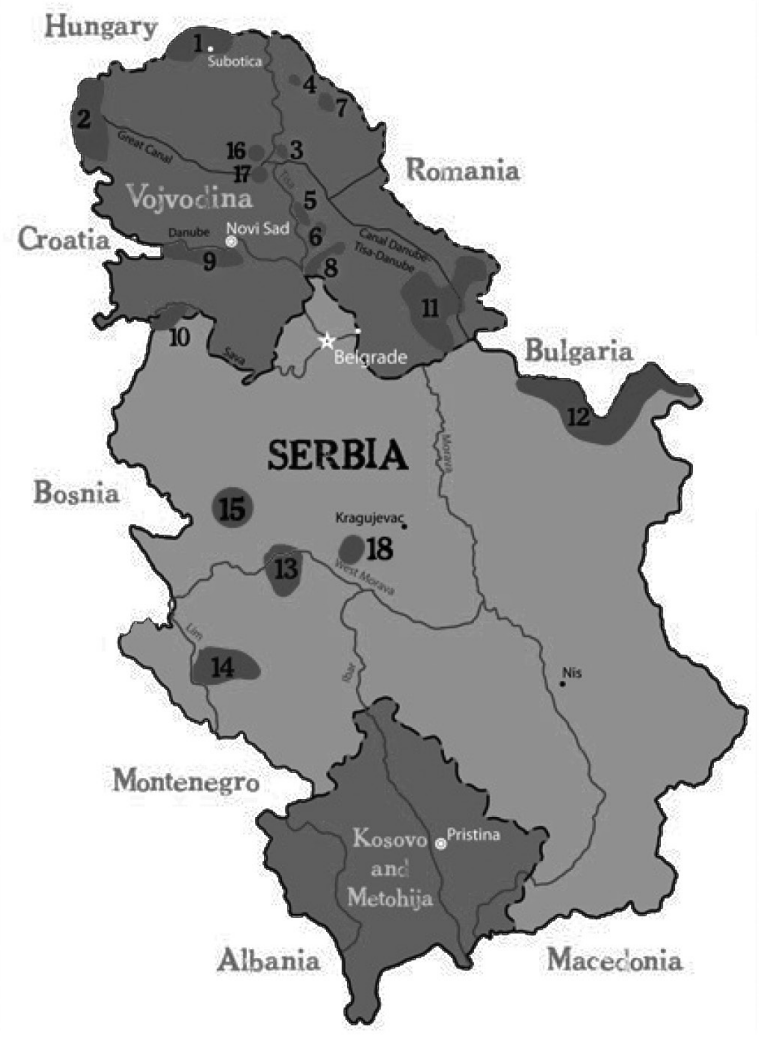

Figure 2. Birding areas in Serbia

Source: Birdwatch Serbia

\section{BIRDWATCHING IN BELGRADE}

Although Belgrade cannot compete with the most attractive birdwatching locations such as Madeira, Portugal, Loop Head, Ireland, Nin, Croatia, North Yorkshire, the UK, Extremadura, Spain (Best Bird Watching Destinations in Europe, 2021), Belgrade is a rich historical heritage, as rarely a city of two million in Europe is home to a large number of birds. Most bird species do not tolerate urban habitat (Bonier, Martin, Wingfield, 2007), which is why Belgrade is a real rarity among 
urban metropolises. One of the many sites that recommend Belgrade, as an unavoidable destination for all bird lovers, states in its recommendation that it can confirm with certainty that there are more than 350 species of birds in Belgrade in Serbia, while highly urbanized urban areas of Belgrade keep almost 100 birds, on the periphery has more than 200 species (Simić, 2017). Rare benefits thanks to which Belgrade can offer this type of tourists such a large number of birds, it is necessary to brand in order for tourists around the world to be familiar with its offer.

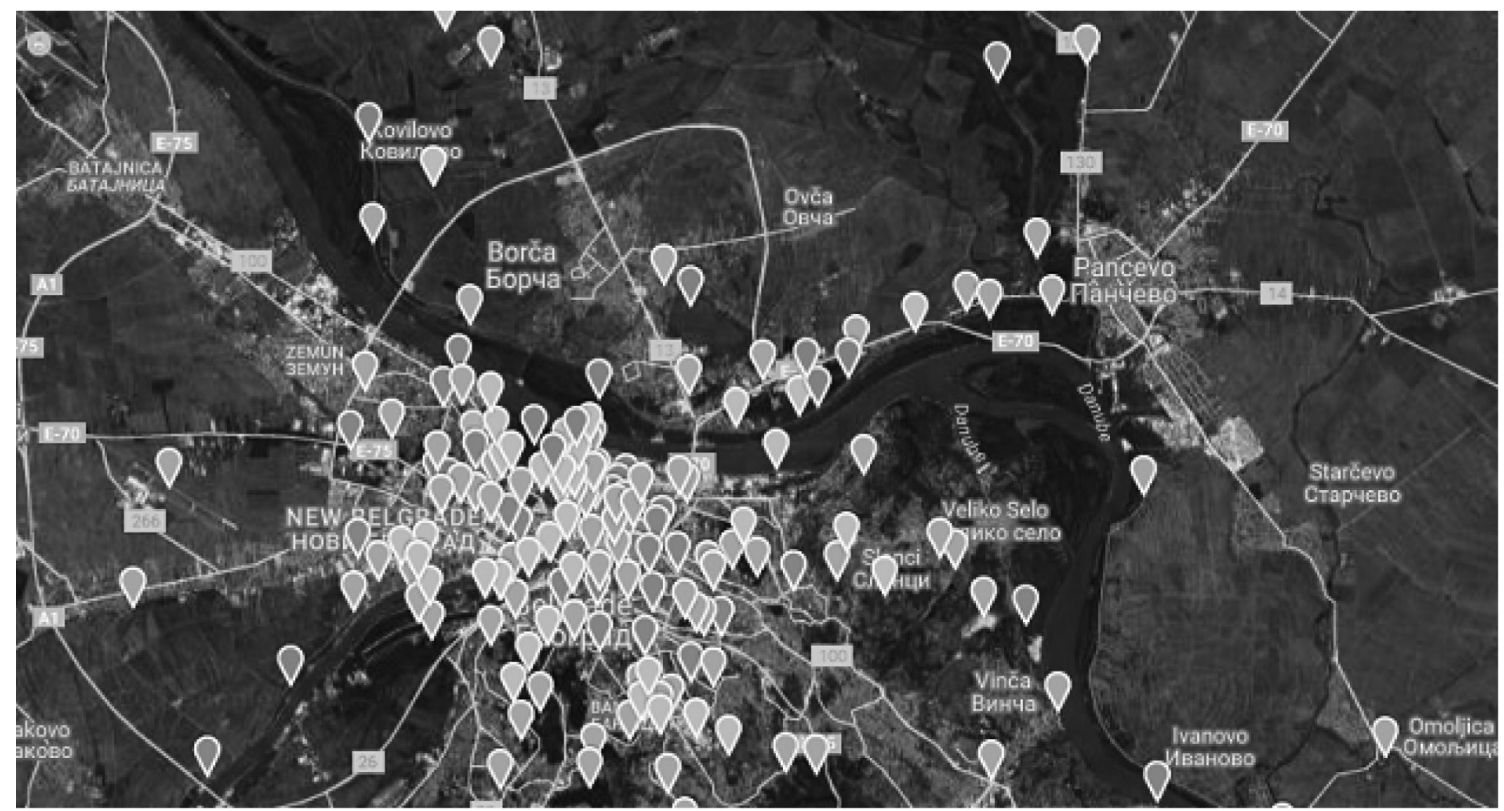

Figure 3. Hotspot map of Belgrade

Source: Simić, 2017

Different conditions have influenced the fact that about 210 different species of birds can be seen in the Belgrade sky. The biggest reason is the geographical position of Belgrade, the river flows are corridors for the migration of birds, two large rivers, the Danube and the Sava. Very close to the central city center there are numerous river branches, ponds and flood zones that are a suitable habitat for many bird species.

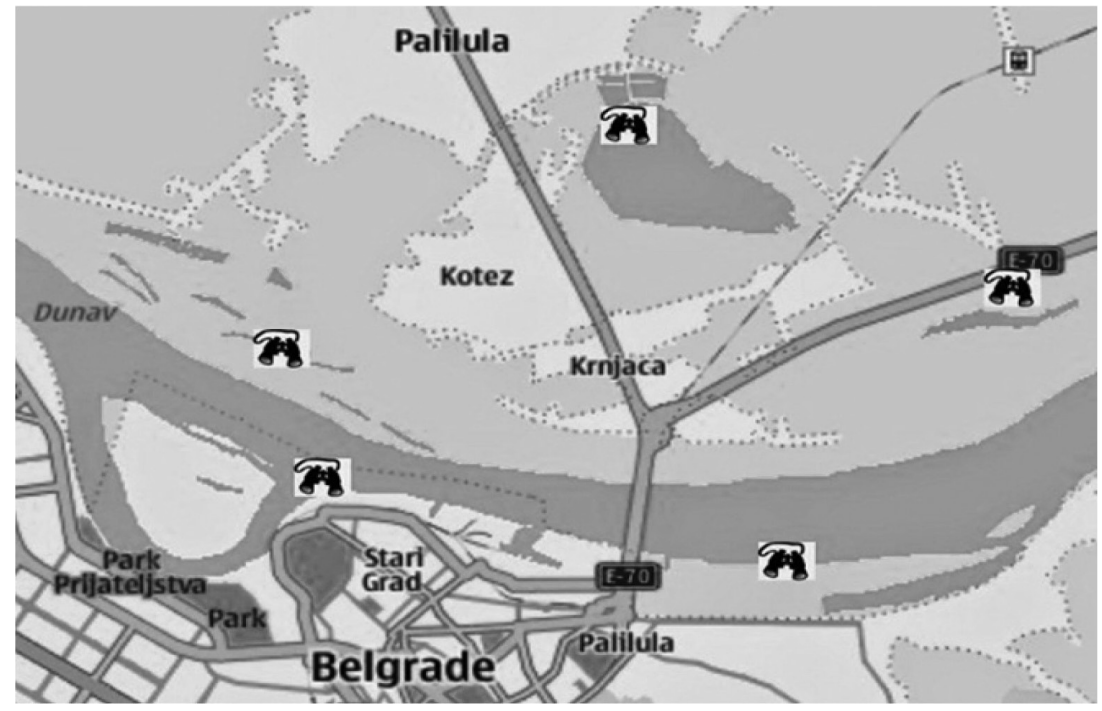

Figure 4. Top 5 places to watch birds in Belgrade

Source: Simić, 2017 
Numerous animal species have adapted to human proximity (Møller, 2009), and show clear cognitive differences relative to the same species living in rural areas. The urban structure of habitats, as well as their proximity, influences the easier availability of food through anthropogenic factors, which significantly influences the appearance of predatory bird species that inhabit cities in search of more abundant prey (Chace, Walsh, 2006). For example, the panorama of Belgrade is often adorned with a white-tailed eagle that flies over its roofs in search of food.

Bird watchers in urban areas are also attracted by the fact that some of the wild birds that live in cities change their song, primarily due to the higher noise level, some of them sing in a higher key (Paunović, 2013).

The confluence of the Sava and the Danube has 167 species of birds, of which bird watchers noticed 104 species according to the last check-in.

\section{VELIKO RATNO OSTRVO - GREAT WAR ISLAND}

The landscape of exceptional features of the Great War Island is the point of the greatest biodiversity of Belgrade. At the confluence of the Sava and the Danube, between the Belgrade fortress and the Zemun medieval fortress, there is a green oasis that has the diversity and richness of the animal world, characteristic of the flood zones of the Danube and the Sava. In 2005, the Assembly of the City of Belgrade passed the Decision on placing the natural asset ,Veliko ratno ostrvo" under protection (,Official Gazette of the City of Belgrade”, No. 7/2005) declaring it a protected natural asset. The goal of that solution is to preserve picturesque landscape features and undisturbed primary landscape values which are of exceptional importance for the preservation of habitats of natural rarities, rare and endangered wetland birds, as well as for the protection of a representative morphological and geological formation - a river island.

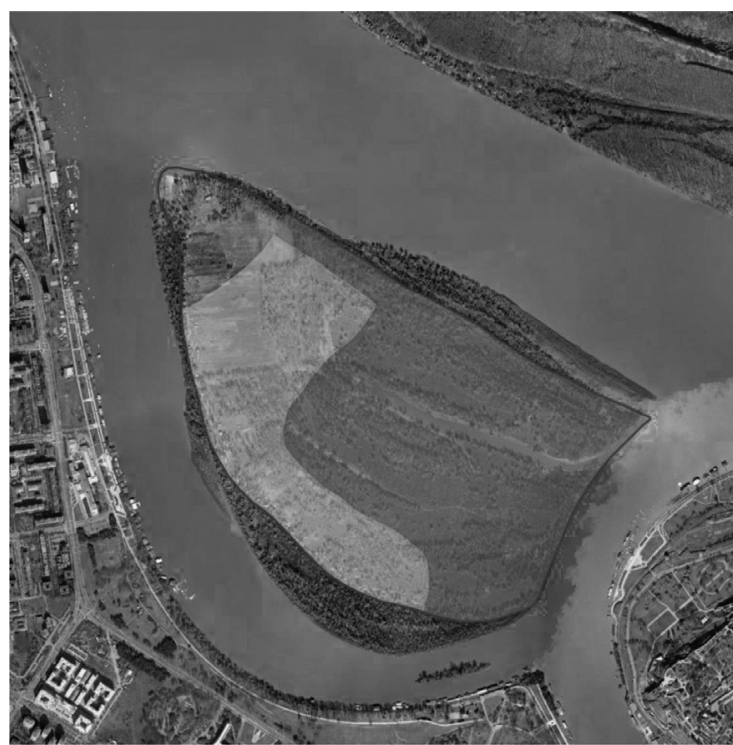

$\square$ Borders of Protected areas

Regime I

Regime II

Figure 5. Borders of Protected areas Veliko ratno ostrvo

Source: Institute for Nature Protection (Zavod za zaštitu prirode), 2012

Thanks to the well-preserved aquatic and wetland vegetation, a large number of migratory and resident birds are present, where more than 5,000 different bird species can be observed in the winter (Veselinović et al., 2006). 
On this island, which is located in the city center, you can meet 163 species, classified into 46 families and 16 orders (Management Plan of the Landscape of Outstanding Features „Great War Island" 2011-2020). On an area covering almost 170 ha, three zones with different protection regimes have been identified: Nature protection zone - protection regime of the first degree which has the character of a special nature reserve (coast, forest complex and wetlands within the island); Recreation zone - protection regime of the II degree (inner parts of the Great War Island) and Tourism zone - protection regime of the III degree which includes (Lido beach with planned expansion).

The proximity of this protected area to the city center enables observation that does not require any equipment, not even going to nature, but more than 90 species of birds can be observed from the Belgrade promenades (Zemun Quay or Dorcol Promenade).

The eBird portal (https://ebird.org) is one of the most relevant real-time birdwatching databases on bird distribution and abundance and on which passionate birdwatching enthusiasts confirm the current presence of bird species at birdwatching sites, in January 2021 confirmed the current presence of 141 species in Belgrade (out of 288 registered): Tawny Owl (Strix aluco), Labud grbac (Cygnus olor), Black swan (Cygnus atratus), Northern shoveler (Anas clypeata), Common pochard (Aythya ferina), Ferruginous duck (Aythya nyroca), Eurasian Nuthatch (Sitta europaea), Velvet Scoter (Melanitta fusca), Black-necked Grebe (Podiceps nigricollis), European robin (Erithacus rubecula), Eastern Olivaceous Warbler (Eastern Olivaceous Warbler), Song thrush (Turdus philomelos), Eurasian wryneck (Jynx torquilla), European turtle dove (Streptopelia turtur), Black Woodpecker (Dryocopus martius), Wood Warbler (Phylloscopus sibilatrix), Common Chiffchaff (Phylloscopus collybita), Mistle Thrush (Turdus viscivorus), Greater white-fronted Goose (Anser albifrons), Marsh Warbler (Acrocephalus palustris), Canada Goose (Branta canadensis), Greater Scaup (Aythya marila), European pied flycatcher (Ficedula hypoleuca), River Warbler (Locustella fluviatilis), Savi's Warbler (Locustella luscinioides), Shorttoed Treecreeper (Certhia brachydactyla), Black Stork (Ciconia nigra), Spotted Woodpecker (Leiopicus medius), Collared Flycatcher (Ficedula albicollis), Peregrine Falcon (Falco peregrinus), Cranes (Gruidae), Garganey (Anas querquedula), Dunnock (Prunella modularis), Longtailed Duck (Clangula hyemalis), Common Eider (Somateria mollissima), Common Shelduck (Tadorna tadorna), Oystercatchers (Haematopodidae), Black kite (Milvus migrans), Ruddy Shelduck (Tadorna ferruginea), Caspian tern (Hydroprogne caspia), Eurasian skylark (Alauda arvensis), Mute swan (Cygnus olor), Black-headed Gull (Larus ridibundus), Yellow-legged Gull (Larus michahellis), Pygmy Cormorant (Phalacrocorax pygmeus), Great Cormorant (Phalacrocorax carbo), Lesser Black-backed Gull (Larus fuscus), European herring gull (Larus argentatus), Black redstart (Phoenicurus ochruros), European goldfinch (Carduelis Carduelis), Mallard (Anas platyrhynchos), Caspian gull (Larus cachinnans), Common gull (Larus Laridae Linnaeus), Eurasian Jackdaw (Corvus monedula), Hooded crow (Corvus cornix), Grey Wagtail (Motacilla cinerea), Common Wood Pigeon (Columba Columbidae Linnaeus), Common wood pigeon (Columba palumbus), Great Black-backed Gull (Larus marinus Linnaeus), Grey Heron (Ardea cinerea), Eurasian sparrowhawk (Accipiter nisus), Eurasian magpie (Pica pica), Rook (Corvus frugilegus), Great tit (Parus major), Eurasian tree sparrow (Passer montanus), Common gull (Larus canus), Common Pheasant (Phasianus colchius), Common moorhen (Gallinula chloropus), Long-tailed tit (Aegithalos caudatus), Eurasian wren (Troglodytes troglodytes), House sparrow (Passer domesticus), White wagtail (Motacilla alba), Old world warbler sp. (Passeriformes sp.), Loons (Gavia Gaviidae Forster), Great black-backed gull (Larus marinus), African Stonechat (Saxicola torquata), Eurasian collared dove (Streptopelia decaocto), Eurasian hobby 
(Falco subbuteo), Red-backed shrike (Lanius collurio), Barn swallow (Hirundo rustica), Common swift (Apus apus), Little ringed plover (Charadrius dubius), Common sandpiper (Actitis hypoleucos), Common Tern (Sterna hirundo), Little egret (Ergetta Garzetta), Common kestrel (Falco tinnunculus), Common whitethroat (Sylvia communis), Common Starling Catalan (Sturnus vulgaris), Common nightingale (Luscinia megarhynchos), Eurasian blackcap (Sylvia atricapilla), Lesser Whitethroat (Sylvia curruca), Common redstart (Phoenicurus phoenicurus), Finch (Fringillidae), European serin (Serinus serinus), Black-crowned night heron (Nycticorax nycticorax), Old World orioles (Oriolidae), Common house martin (Delichon urbicum), Blackwinged stilt (Himantopus himantopus), Wood sandpiper (Tringa glareola), Bee-eater (Meropidae), Whinchat (Saxicola rubetra), Western yellow wagtail (Motacilla flava), European greenfinch (Chloris chloris), White-tailed eagle (Haliaeetus albicilla), Tree pipit (Anthus trivialis), Eurasian hoopoe (Upupa epops), White stork (Ciconia ciconia), Hawfinch (Coccothraustes coccothraustes), Common buzzard (Buteo buteo), Green sandpiper (Tringa ochropus), Common chiffchaff (Phylloscopus collybita), European robin (Erithacus rubecula), Coal Tit (Parus Peripatus ater), Syrian woodpecker (Dendrocopos syriacus), Long-eared owl (Asio otus), Greylag goose (Anser), Eurasian blue tit (Cyanistes caeruleus), Common reed bunting (Emberiza schoeniclus), Eurasian Wigeon Catalan (Anas penelope), Northern goshawk (Accipiter gentilis), Whiskered tern (Chlidonias hybrida), Common kingfisher (Alcedo atthis), Fieldfare (Turdus pilaris), Larus (Larinae sp.), Eurasian siskin (Spinus spinus), Eurasian coot (Fulica atra), Eurasian jay (Garrulus glandarius), Willow Warbler (Phylloscopus trochilus), Great Egret (Egretta alba), Squacco heron (Ardeola ralloides), Great Spotted Woodpecker (Dendrocopos major), Common cuckoo (Cuculus canorus), Lesser grey shrike (Lanius minor), House sparrow (Passer domesticus), Tawny Pipit (Anthus campestris), Great reed warbler (Acrocephalus arundinaceus), Red-breasted merganser (Mergus serrator), Great crested grebe (Podiceps cristatus), Lesser white-fronted goose (Anser erythropus), Common blackbird (Turdus merula), Little grebe (Tachybaptus ruficollis), Common chiffchaff (Phylloscopus collybita), Western marsh harrier (Circus aeruginosus), Hen harrier (Circus cyaneus), Eurasian teal (Anas crecca), Gadwall (Anas strepera), Red-breasted merganser (Mergus serrator), European green woodpecker (Picus viridis), Spotted Flycatcher (Muscicapa striata), Common Merganser (Mergus Merganser), Northern Wheatear (Oenanthe oenanthe), Pallas's Gull (Ichthyaetus ichthyaetus), Common Goldeneye (Bucephala clangula) (eBird, Veliko Ratno Ostrvo).

Fans of bird watching as top hotspots for birdwatching in Belgrade list the following locations: Dorćol quay (143 currently confirmed bird species), Veliko ratno ostrvo (141), Reva lake (135), Kotež floodplain (135), Galovica (131), Veliko blato lake NR / Mika Alas fish farm (127), Krnjača (120), Jakovački ključ/Surčin (116), Čapljin (107), Bojčinska šuma (106), Ada Huja (104), Guberevačke šume (103), Ada Ciganlija (96), Beli potok (91), Kalemegdan (89), Savski nasip/ blokovi 45,44,70, 70a (88), Vinča bara (87), Crvenka (86), Topčiderski park (82), Zvezdarska šuma (82), Avala (78).

BirdLife International, the world's umbrella organization of ornithologists, based on biogeographical and ecological conditions, assesses the areas according to their international importance for birds, their entry into international registers, and the implementation of adequate protection measures (Puzović, Grubač, 1998). Areas that meet these criteria are defined as International Important Bird Areas (IBAs). On the territory of Belgrade, it is the confluence of the Sava and the Danube, with the following points: Veliko ratno ostrvo, Kotež floodplain, Reva lake, Veliko blato lake NR / Mika Alas fish farm, Krnjača, Ada Huja, Čapljin, Vinča bara and Crvenka. 
The special feature of Belgrade's offer is complemented by the multitude of birdwatching sites located near Belgrade, which offer a different atmosphere of bird watching with more direct interaction with nature. Among these locations, the area of Deliblato Sands stands out where some of the rare species can be observed, such as Imperial eagle (Aquila heliaca), Corncrake (Crex crex) and Saker falkon (Falco cherrug) (Mitchel, 2013).

\section{CONCLUSION}

It is necessary to train and license tourist guides who specialize in bird watching, to encourage travel agencies to get involved in promoting this type of tourism. Tourist organizations, as an invaluable link between tourists, accommodation facilities and local tourist organizations, when we talk about this branch of tourism, have an incomparably easier job when it comes to promoting and attracting tourists. Primarily because bird watchers are predominantly members of local organizations for bird watching, nature conservation and the like. Therefore, it is incomparably easier to target and focus on the promotion of such a tourist offer.

The tourist potential for bird watching on the territory of Belgrade is great but insufficiently used. It seems that it is necessary to primarily brand birdwatching as a hobby in Serbia, especially among the leaders of local communities, travel agencies, owners of tourist facilities, etc. to recognize the opportunities that this type of tourism can provide them. This would achieve the necessary synergy, and provide more significant assistance to birdwatching enthusiasts who are the best promoters of this hobby, but also of our natural beauties.

\section{REFERENCES}

Best Bird Watching Destinations in Europe, European Best Destinations, available at: https://www. europeanbestdestinations.com/best-of-europe/best-birdwatching-destinations-in-europe/ (Accessed 05.03.2021)

Birdwatch Serbia, available at: http://www.birdwatchserbia.rs/ (Accessed 05.03.2021)

Birdwatching tourism from Europe, CBI, Ministry of Foreign Affairs (2017), available at: https:// www.cbi.eu/market-information/tourism/birdwatching-tourism (Accessed 05.03.2021)

Bonier, F., Martin, P. R., Wingfield, J. C. (2007). Urban birds have broader environmental tolerance, Biology letters, 3(6), 670-673.

Chace, J. F., Walsh, J. J., (2006). Urban effects on native avifauna: a review, Landscape Urban Plann., 74, 46-69.

Dašić, G., Anufrijev, A. (2018). Determinants of Green Economy development and promotion in ecotourism, Ecologica, 25(92), 805-810.

Durdić, S., Stojaković, S., Šabić, D. (2011). Nature conservation in urban conditions: A case study from Belgrade, Serbia, Maejo International Journal of Science and Technology, 5(1), 129-145.

Gobe, M. (2001). Emotional Branding: The New Paradigm for Connecting Brands to People. New York: Allwort Press, p. 25.

Hinchliffe, S. (2010). Where Species Meet, Environment and Planning D: Society and Space, 28(1), 34-35.

Ilić, B., Trandafilović, I., Jovanović, L. (2017). Building a spa destination brand of Serbia, Ecologica, 24(88), 910-914.

Kerlinger, P. (1992). Birding Economics and Birder Demographics Studies Conservation Tools, In: Finch, Deborah M. \& Stangel, Peter W. (eds.), Status and management of neotropical migratory birds: September 21-25, Estes Park, Colorado (pp. 32-38). Gen. Tech. Rep. RM-229. Fort 
Collins, Colo.: Rocky Mountain Forest and Range Experiment Station, U.S. Dept. of Agriculture, Forest Service.

Kolstoe, S., Cameron, T.A. (2017). The non-market value of birding sites and the marginal value of additional species: biodiversity in a random utility model of site choice by eBird members, Ecological Economics, 137, 1-12.

Lakićević, M., Srđević, B. (2011). Turistička valorizacija Topčiderskog parka u Beogradu, Letopis naučnih radova Poljoprivrednog fakulteta, Novi Sad, 35(1), 127-135.

Malinić, V. (2016). Urbani ekoturizam kao koncept optimalnog razvoja PIO ,Veliko ratno ostrvo', Zbornik radova - Geografski fakultet Univerziteta u Beogradu, 64, 481-516.

Marković, S., Božović, S., Vukoičić, D., Ristić, D. (2018). Bioclimatic resources of mountain resorts in function of green tourism development of Serbia, Ecologica, 25(90), 418-423.

Milićević, S., Đorđević, N., Krejić, Ž. (2019). Krupajsko vrelo kao nova eko-turistička destinacija Srbije, Ecologica, 26(96), 481-486.

Mitchel, L. (2013). Serbia: The Bradt Travel Guide, edition 4, Bradt Travel Guide Ltd, p. 294.

Mladenović, M., Bojičić, R. (2020). Razvoj ekoturizma u opštini Štrpce-mogućnosti i perspektive. Ecologica, 27(98), 232-239.

Møller, A.P. (2009). Successful city dwellers: a comparative study of the ecological characteristics of urban birds in the Western Palearctic, Oecologia, 159, 849-858.

Morgan, N., Pričard, A., Prajd, R. (2015). Destinacija kao brend. Beograd: Clio, p. 26.

Municipalities and regions of the Republic of Serbia. The Statistical Office of the Republic of Serbia, Belgrade, 2020, p. 280.

National Survey of Fishing, Hunting, and Wildlife-Associated. (2016), U.S. Fish \& Wildlife Service and U.S. Census Bureau, available at:https:/www.fws.gov/wsfrprograms/subpages/nationalsurvey/nat_survey2016.pdf (Accessed 07.03.2021)

Okanović, A., Ješić, J., Vukadinović, S. (2020). Mogućnosti upotrebe eko-oznaka u zelenim kampusima, Ecologica, 27(100), 624-632.

Olins, V. (2003). On Brand. London: Thames \& Hudson Ltd, p. 172.

Paunović, A. (2013). Ptice u gradovima, Planeta, 57, available at: http://www.planeta.rs/57/19ptice. htm\#.YA6_R3ZKiM8 (Accessed 05.03.2021)

Plan upravljanja Predela izuzetnih odlika „Veliko ratno ostrvo” 2011-2020, JKP Zelenilo Beograd.

Puzović, S., Grubač, B. (1998). Lista područja u Srbiji [Jugoslavija] od međunarodnog i nacionalnog znacaja za očuvanje diverziteta faune ptica, Zaštita prirode, Zavod za zaštitu prirode Srbije, Beograd, 50, 189-197.

Rajević, S., Novaković, R., Đuričić, M. (2016). Birdwatching tourism in Serbia. 3rd International Conference: „Higher education in function of development of tourism in Serbia and Western Balkans" (pp. 527-539), Užice: Business and Technical College of Vocational Studies.

Schultz, D. E., Barnes, B. E. (1999). Strategic brand communication campaigns. Bandung: Lincolnwood: NTC Business Books, p.7.

Simić, D. (2017). City Guide: Finding Birds in Belgrade, 10,000 Birds, Birding, nature, conservation and the wide, wide world, available at: https://www.10000birds.com/city-guide-findingbirds-in-belgrade.htm (Accessed 28.01.2021)

Stanković, M. (2021). Pregled ptica grada Sremska Mitrovica, Ecologica, 28(101), 36-42.

Stavretović, N., Petrović, J., Đurić, M. (2011). Invazivne biljne vrste u travnim površinama nekih parkova Beograda, Acta herbologica, 20(2), 121-131.

Stojanović Karanović, E., Sretenović, M., Imamović, E. (2011). O projektu „Beogradske perpsektive održivog razvoja i klimatskih promena". In: Beogradske perspektive održivog razvoja i klimatskih promena, Međunarodni forum „Dunav - reka saradnje” (pp. 13-33). 
Strategija razvoja turizma Grada Beograd 2020-2025. (2019). Centar za istraživanja i studije turizma. Grad Beograd, Sekretarijat za privredu, p. 26.

Šćiban, M., Rajković, D., Radišić, D., Vasić, V., Pantović, U. (2015). Ptice Srbije - kritički spisak vrsta. Novi Sad: Pokrajinski zavod za zaštitu prirode i Društvo za zaštitu i proučavanje ptica Srbije, p. 194.

Štetić, S., Cvijanović, D., Šimičević, D. (2014). Posebni oblici turizma Dunavskog regiona Srbije, Beograd: Institut za ekonomiku poljoprivrede, p. 157.

Štetić, S., Trišić, I. (2020). Prirodni resursi za razvoj ekoturizma Specijalnog rezervata prirode «Obedska bara». Ecologica, 27(98), 224-231.

Todorović, M. Štetić, S. (2009). Ruralni turizam. Beograd: Geografski fakultet, p. 50.

Veliko Ratno Ostrvo (Great War Island) - VRO, Belgrade, eBird, available at: https://ebird.org/hotspot/L2209173?yr=all\&m=\&rank=mrec (Accessed 26.01.2021).

Veselinović, M., Golubović-Ćurguz, V., Nikolić, B., Nešić, N., Cvejić, M. (2006). Neka zaštićena prirodna dobra na području gradske zone Beograda, In: Scientific conference „Management of forest ecosystems in national parks and other protected areas", Zbornik radova, Jahorina NP Sutjeska (pp. 137-143).

Virijević Jovanović, S., Doljanica, S., Janovac, T. (2020). Green economy in Iceland: an engine for tourism development, Ecologica, 27(100), 639-646.

Vujović, S., Cvijanović, D., Štetić, S. (2012). Destinacijski koncept razvoja turizma. Beograd: Institut za ekonomiku poljoprivrede, p. 65.

White, J. (2019). How popular is birdwatching? Chirp Birding, available at: https://chirpbirding. com/blog/81/how-popular-is-birdwatching/ (Accessed 07.03.2021)

Zaštićeno područje „Zvezdarska šuma”, spomenik prirode, Javno komunalno preduzeće Zelenilo-Beograd, available at: https:/www.zelenilo.rs/delatnosti/zasticena-prirodna-dobra/zasticeno-podrucje-zvezdarska-suma-spomenik-prirode (Accessed 13.02.2021)

Zavod za zaštitu prirode, Veliko ratno ostrvo: predeo izuzetnih odlika, available at: https://www. zzps.rs/wp/veliko-ratno-ostrvo/?script=lat (Accessed 07.03.2021)

Živković, D. (2018). Managing a tourism destination from a sustainable development aspect, Ecologica, 25(91), 827-832. 